\title{
Comparative Analysis of the Practice of Internet Use in the Marketing Activities of Higher Education Institutions in Poland and Ukraine
}

\author{
Artur Kisiołek \\ Ph.D., Professor, Head of the Department of Economics, The Great Poland \\ University of Social and Economics in Środa WIkp., Środa WIkp., Poland \\ e-mail: a.kisiolek@wwsse.pl
}

Oleh Karyy

Ph.D., Professor, Head of the Department of Management of Organizations Lviv Polytechnic National University, Lviv, Ukraine, e-mail: Oleh.I.Karyi@lpnu.ua

\author{
Liubov Halkiv \\ Ph.D., Professor, Department of Management of Organizations \\ Lviv Polytechnic National University, Lviv, Ukraine \\ email: Lyubov.I.Halkiv@Ipnu.ua, lubakram2015@gmail.com
}

\begin{abstract}
In the information age, the role of higher education as a factor of social progress is increasing. The competition among higher education institutions is also growing. This requires higher education institutions' (HEls) marketing policies to be diversified, digitalized, and integrated into the virtual space. In order to find out the role and importance of Internet tools and in marketing activities, a questionnaire survey was conducted among managers and specialists of HEls in Ukraine and Poland. The data served as the basis to study the level of variation, structure similarity, and consistency of the generalized responses of the respondents of the two countries. We verified hypotheses about (1) the absence of significant differences between the estimates of the role of the Internet in the marketing activities of HEls in Poland and Ukraine; (2) the consistency of answers of the respondents of the two countries regarding the use of the Internet in market activites of HEls; (3) HEls' use mostly geo-targeting potential consumers of higher education online.
\end{abstract}


The dominant feature of the Internet - quick access to information - enables effective marketing activities. The management of HEls should increase the awareness of their marketing staff in using the Internet to expand the delivery of educational services, intensify interviewing practices for obtaining feedback from customers, attract sponsors, promote their own brands, do market research, and so on.

Keywords: higher education institution, marketing activity, Internet-marketing, marketing communications, structure similarities, variations, rank correlation

JEL: I23, M3, P52

\section{Introduction}

In the $21^{\text {st }}$ century, world-leading institutions have recognized the growing role of higher education in socio-economic transformations. That is why scientists are now positioning a country's higher education system country as the main driver of national economic and social progress. The effectiveness of the higher education influence on these socio-economic changes depends from an array of prerequisites. Among these prerequisites, we can distinguish three significant positive social roles performed by the higher education environment:

- the realization of the mission of the main source of knowledge;

- the promotion of economic innovations through the formation of human capital and intellectual potential;

- ensuring that social systems are highly competitive and sustainably developed.

The formal providers of higher education services are traditionally higher education institutions (HEIs). HEIs should be understood as institutions of a particular kind with the following characteristics:

- it is a legal entity under private or public law;

- it implements activities at certain levels of higher education;

- it disseminates and generates new knowledge to achieve individual and institutional development goals of social systems;

- it develops the intellectual potential of the recipients (consumers) of its services and prepares them for sustainable employment and active citizenship.

The leading measure of HEIs' performance efficiency is how they interact with internal and external stakeholders. In particular, the production of necessary impact on the target consumer in the process of communication is essential for improving their efficiency. HEIs can produce the necessary impact not only with public relations tools, training courses and program offers, promotion of their teaching personnel but also through promoting the institution's values, in particular, students' or graduates' successes (e.g., grants that have been awarded, completed projects, career progress, socially responsible behavior, etc.). 
The new economy of the information age puts new demands on digitalizing the communication tactics and strategies of HEIs. There is no doubt that today, the problem of improving the efficiency of marketing communications of HEIs cannot be solved without considering their marketing activities on the Internet. The key benefits of Internet marketing include interactivity, quality targeting, lack of territorial restrictions, accessibility, and the possibility of post-click analysis, among others.

These global trends also suggest that a comparative analysis of the practice of using e-marketing by HEIs in different countries will not lead to radically different estimates (results). The similarity of the neighboring countries in the size of the population and the number of HEIs made it expedient to implement a research project on the example of Poland and Ukraine, some results of which are presented in this article.

\section{Analysis of recent research and publications on the selected topic}

An analysis of a selection of Ukrainian electronic scientific periodicals available on the V. Vernadsky National Library website revealed that among the main topics of marketing HEIs via the Internet, the following have been brought up:

- research into the characteristics of electronic marketing tools use by Ukrainian universities and the rationale for reorganizing marketing departments through the creation of an informational and analytical sector and marketing communications sector (Petrunya \& Petrunya 2018);

- a description of the advantages provided by the building a university's image on the Internet (mass and geographic scale; continuous access; feedback; flexibility; efficiency and completeness of information; minimum expenses), and characteristics of the main Internet technologies and tools to create and manage a university's image on the Internet: Websites, website search engine optimization; thematic groups; viral Internet-marketing; direct Internet-marketing; advertising and publishing information on informational web sites, blogs, and forums (Beztelesna \& Vasyliv 2016);

- identifying marketing tasks in the process of implementing distance learning in Ukrainian HEIs and describing tools worth using for distance learning promotion: targeted advertising on social networks, targeted advertising on educational websites, contextual advertising, banner advertising, web-analytics (Zabolotskiy 2016);

- an assessment of the capabilities of Internet marketing tools and methods, and the rationale for their complex application by higher education institutions in order to promote their scientific and educational services according to differences between on-line and off-line marketing communications - the new set of knowledge, skills, experience, beliefs, personell behavior and relationships, their readiness and ability to apply Internet-technologies effectively in various aspects 
of scientific and educational activities in order to gain economic or other benefits (Illiashenko 2014);

- the use of the smartphone application "Instagram" as an Internet marketing tool for social communications to promote the brands of HEIs and their subdivisions (Mozgova \& Kolosovska \& Onishchenko 2017);

- digital communication strategies in marketing higher education services (Daynovskyy \& Semak \& Boychuk 2018; Prosovych \& Botsman 2018);

- identifying the non-systemic implementation of a business model in higher education that is based on Marketing 4.0, and the development of an organizational and management mechanism for social media marketing strategy formation and implementation in HEIs (Zhehus 2018).

The latest scientific research in the field of HEIs' marketing communications in Poland mainly concerns the use of social media. Integration into the virtual space, which involves the provision of services via the Internet, electronic advertising, and positioning in search engines, has become an integral element of university marketing strategies (Buchnowska 2013). Generation Z (post-Millennials), which significantly affects the make-up of the modern cohort of students, forces the management of higher education institutions to more actively use IT-technologies in marketing communications to benefit the following: "the possibility of 'closer relationship' of individual stakeholder groups and their deeper relationship with the university; rapid flow of information (opinions, experiences, advice, and recommendations) between the university and different staholders, particulary important for the candidates seeking information about studies on the first year and second level of study and for choosing a major of study" (Hall \& Peszko 2016). Based on research of 403 higher education institutions available on the Ministry of Science and Higher Education of Poland website in 2018, the highest popularity of the Facebook website has been proven against the backdrop of the increased use of several profiles on other social networks: YouTube; Twitter; Google+; Instagram; LinkedIn (Wojciechowska 2018).

The issue of marketing communication with the use of the new media is inscribed in the concept of $360^{\circ}$ marketing, which comprises several means of communication, e.g., websites, search engine marketing, direct marketing, social media marketing, and Internet advertising. These instruments have been researched by 320 companies in the B2B sector in both Polish and foreign markets (Bartosik-Purgat 2018). The same sector of the new media, this time with reference to the market of higher education, is presented in the monograph edited by the researchers from the University of Economics in Katowice (Smyczek \& Matysiewicz 2015).

Leading international scientists and sociologists recognize the importance of the Internet in improving the information provided to prospective students and in the personnel recruitment process at universities (Table 1). At the same time, trends that contribute to the greater efficiency of HEIs' activity on the Internet and which are used in marketing include: 
- simplifying the user interface by using a website that is intuitive and accessible on different devices or platforms;

- search engine optimization (SEO), which puts the institution higher up the list of search results;

- initiating communication in the form of online lectures, real-time chats with university representatives and bloggers, and guest posts in discussion forums;

- improving the analysis of the marketing activities results, based on a wide range of available information and Internet-analytics;

- developing communication by expanded investment in banner advertisements, promotional articles, robo-calls, and apps for mobile Internet users on markets of educational, training, informational, innovative and other services;

- improving content-management by means of the personalization pyramid ( 1 - search engine optimization; 2 -segmentation; 3 - content orientation to a specific person).

Table 1. The main digital marketing strategies of higher education institutions

\begin{tabular}{|l|l|}
\hline \multicolumn{1}{|c|}{ Strategy } & \multicolumn{1}{c|}{ Facts } \\
\hline Video Advertisements & $\begin{array}{l}\text { It is estimated that 65\% of the population learn better by seeing } \\
\text { images rather than reading words }\end{array}$ \\
\hline Personal Voice Assistants & $\begin{array}{l}\text { It is estimated that about 60\% of households use Voice Assistants } \\
\text { in USA }\end{array}$ \\
\hline $\begin{array}{l}\text { Accessibility on mobile } \\
\text { devices }\end{array}$ & $\begin{array}{l}\text { It is estimated that 60\% of all internet traffic comes from mobile } \\
\text { devices }\end{array}$ \\
\hline SMM & $\begin{array}{l}\text { It is estimated that a billion people use social media. There is a need } \\
\text { to reorient strategies from well-known news feeds and focus } \\
\text { on capturing the attention in "Stories". }\end{array}$ \\
\hline SEO & $\begin{array}{l}\text { It is estimated that 93\% of people use a search engine to begin surfing } \\
\text { the web }\end{array}$ \\
\hline Email & $\begin{array}{l}\text { On average, more than 2\% of promotional emails are read in their } \\
\text { entirety }\end{array}$ \\
\hline
\end{tabular}

Source: authors' own elaboration based on the data of e-resources (The 7 hottest higher ed digital marketing trends for 2019. Retrieved from: https://www.higher-education-marketing.com; The Most Important 2019. Higher Education Marketing Trends. Retrieved from: https://linchpinseo.com (accessed: 10.07.2019).

\section{Characteristics of HEls and the array of empirical data}

Higher education institutions use a wide range of Internet possibilities in their operational activities. In order to identify the role of Internet tools and their importance in the marketing activities of higher education institutions, a questionnaire survey was carried out on the following subject: "Internet in the activities of higher education institutions." This research project was implemented in Ukraine and Poland between 2015 and 2017. It covered 123 and 62 higher education institutions in each country, 
respectively (more than $10 \%$ of higher education institutions in each country). The issues of data collection techniques and tools are described in a few publications, e.g., Kisiołek 2018; Kisiołek \& Karyy \& Prokopenko 2018.

The research project was based on a questionnaire method (one questionnaire corresponded to one higher education institution) and a sampling observation method to justify the representativeness of the sample. The target group comprised managers and specialists of higher education institutions whose activities focused on marketing. The questions provided from three to seven answer options (depending on the essence of the question). The empirical data obtained in the course of the project was used to ascertain the level of structural similarity and consistency of the respondents' responses in both countries, and to identify ties between individual factors.

\section{Hypotheses of the research}

The authors hypothesize: 1 - there are no significant differences in structural responses between the assessments of the Internet in marketing activities of Polish and Ukrainian higher education institutions; 2 - there is consistency between HEIs in the two countries regarding Internet use in marketing activities, and therefore there are strengths and weaknesses in these practices: 3 - there is an order of preferable criteria (geographic, demographic, behavioral) of targeting the audience of HEIs.

\section{Research methodology}

Within this article, the similarity coefficient of structures was used for the two arrays of data in order to assess the level of similarity of structural responses of respondents in Poland and Ukraine:

$$
P=1-\frac{1}{2} \sum_{j=1}^{m}\left|d_{j}^{U}-d_{j}^{P}\right|,
$$

where $d_{j}^{U}$ - is the share of $j$ 's response of respondents of Ukraine; $d_{j}^{P}$ - is the share of $j$ 's response of respondents of Poland.

The following indicators were used to assess the variation of individual indicators: Coefficient of variation:

$$
\nu_{\sigma}=\frac{\sigma}{\overline{\tilde{o}}} \times 100
$$

Interquartile range of variation:

$$
R_{Q}=Q_{3}-Q_{1}
$$


where $\tilde{O}$ - is the average characteristic value in the range; $\sigma$ - is the standard deviation of the characteristic value in the range; $Q_{3}$ and $Q_{1}$ - are the values of the third and the first quartiles of the characteristic distribution in the range, respectively.

If the value of the coefficient of variation exceeds $33 \%$, the sample is considered heterogeneous, and the average value is considered atypical. If the characteristic value is outside the interquartile range, it is considered an "outlier."

The Spearman coefficient was used to estimate the rank correlation:

$$
\rho=1-\frac{6 \sum d^{2}}{n \times\left(n^{2}-1\right)},
$$

where $n$ - is the number of positions; $d$ - is the difference between the position ranks by country.

The value of $\rho$ varies from -1 to +1 , characterizing the direction and density of the tie. The tie is considered significant (at the significance level of $1-\alpha$ ), if the observed value of $\rho$ exceeds the critical value $\rho_{l} \alpha(n)$.

The Chuprov correlation coefficient $(C)$ was used to assess ties between categorical characteristics:

$$
C=\sqrt{\frac{\chi^{2}}{n \sqrt{\left(m_{x}-1\right)\left(m_{y}-1\right)}}}
$$

where $m_{x}$ and $m_{y}$ are the numbers of the groups according to the factor and efficiency characteristics, respectively; $\chi^{2}-$ is the Pearson chi-squared test:

$$
\chi^{2}=n\left[\sum_{i} \sum_{j} \frac{f_{i j}^{2}}{f_{i \Sigma} \cdot f_{\sum j}}-1\right]
$$

$f_{i j}$ - is the frequency of the characteristic of the $i$-th row (of the $i$-th factor group) on the $j$-th column ( $j$-th efficiency groups); $f_{i \Sigma}$ and $f_{\Sigma j}$ - are total frequencies by groups of factor and efficiency characteristics; $n$ - is the sample size.

The value of $C$ varies from 0 to 1 , characterizing the density of the tie. The tie is considered significant (at the significance level of $1-\alpha$ ), if the observed value of the Pearson chi-squared test $\left(\chi^{2}\right)$ exceeds the critical value $\chi_{1-\alpha}^{2}\left(k=\left(m_{x}-1\right) \times\left(m_{y}-1\right)\right)$.

To summarize the respondents' estimates in the form of rank scales, the indicator of the average centred rank was used:

$$
\bar{R}_{o}=\bar{R}-\frac{R \max +R \min }{2},
$$

where $R_{\max }, R_{\min ,}, \bar{R}$ - are the maximum, minimum, and average values of the ordinal ranks.

If the average centred score is positive, the phenomenon is generally positive. 


\section{The contents and description of the comparative analysis}

The first question of the research project was related to clarifying the role of the Internet in the marketing activities of an HEI. The question comprised 12 items concerning the role of the virtual environment as a certain tool, which: 1 - substantially supports the creation of the image of an HEI; 2 - is cheaper compared to traditional mass media tools that are used in marketing activities; 3 - makes it possible to reach the target groups of potential students in market segments where an HEI operates; 4 - provides an opportunity for clear access to new market segments; 5 - provides an opportunity for quick access to information on the educational services market; 6 - is used to enhance positive interactive communication with students; 7 - helps to improve services for students; 8 - contributes to a better understanding of students' needs; 9 - strengthens the feeling of interaction between an HEI and students; 10 - makes it possible to obtain detailed information about existing and potential students; 11 - helps to implement new elements of the educational offer by an HEI; 12 - supports the implementation of educational services. For each item, one of the three possible answers was offered (see Table 2).

Table 2. Structure and level of similarity of Polish and Ukrainian respondents' responses to the role of the Internet in the marketing activities of higher education institutions

\begin{tabular}{|c|c|c|c|c|c|c|c|}
\hline \multirow{3}{*}{$\begin{array}{c}\text { Number } \\
\text { of the } \\
\text { item }\end{array}$} & \multicolumn{6}{|c|}{ Share of answers, $\%$} & \multirow{3}{*}{$P$} \\
\hline & \multicolumn{2}{|c|}{ agree } & \multicolumn{2}{|c|}{ disagree } & \multicolumn{2}{|c|}{ Difficult to say } & \\
\hline & Poland & Ukraine & Poland & Ukraine & Poland & Ukraine & \\
\hline 1 & 82.1 & 95.2 & 0.0 & 0.0 & 17.9 & 4.8 & 0.869 \\
\hline 2 & 66.7 & 79.1 & 22.0 & 16.1 & 11.4 & 4.8 & 0.875 \\
\hline 3 & 75.6 & 64.5 & 4.1 & 21.0 & 20.3 & 14.5 & 0.831 \\
\hline 4 & 61.0 & 50.0 & 5.7 & 8.1 & 33.3 & 41.9 & 0.891 \\
\hline 5 & 100.0 & 98.4 & 0.0 & 0.0 & 0.0 & 1.6 & 0.984 \\
\hline 6 & 93.5 & 88.7 & 0.8 & 3.2 & 5.7 & 8.1 & 0.953 \\
\hline 7 & 95.1 & 85.5 & 1.6 & 6.4 & 3.3 & 8.1 & 0.901 \\
\hline 8 & 41.5 & 59.7 & 11.4 & 21.0 & 47.2 & 19.3 & 0.722 \\
\hline 9 & 40.7 & 46.8 & 15.4 & 22.6 & 43.9 & 30.6 & 0.865 \\
\hline 10 & 48.0 & 53.2 & 21.1 & 21.0 & 30.9 & 25.8 & 0.948 \\
\hline 11 & 84.6 & 77.4 & 1.6 & 11.3 & 13.8 & 11.3 & 0.905 \\
\hline 12 & 95.1 & 66.2 & 0.0 & 3.2 & 4.9 & 30.6 & 0.712 \\
\hline
\end{tabular}

Source: compiled and calculated by the authors according to their own survey.

The overwhelming majority of the respondents in both countries chose a positive answer in each item. The maximum value for "I agree" (100.0\% of the respondents in Poland and $98.4 \%$ in Ukraine) concerned the statement of the possibility of having quick access to information on the educational services market via the Internet.

For the ninth item - i.e., the Internet strengthens the feeling of interaction between an HEI and students - the scores of Poland and Ukraine were low and quite similar, 
with only $40.7 \%$ and $46.8 \%$ agreeing, respectively. The results were also quite similar when it came to those who disagree with the statement $-15.4 \%$ of Polish respondents and $22.6 \%$ from Ukraine.

The absolute values of the $\mathrm{P}$ coefficient indicate the similarity of the response structures of Polish and Ukrainian respondents. The coefficient of variation calculated on the basis of these values was $9.2 \%$, and the interquartile range of variation was 0.117 . Such values point to (1) the homogeneity of the set of $\mathrm{P}$ values in the context of the 12 considered items; (2) the typicality of the average P value (0.871); (3) the absence of significant "outliers" of its values. The greatest discrepancy between the experts' estimates in the two countries (0.712) is observed in the statement of the role of the Internet in implementing educational services. This discrepancy may hypothetically depend on the ownership form of an HEI. To test the hypothesis, we created a table of mutual correlation. According to the table, 84 out of the 88 respondents who represented private higher education institutions from both countries assessed the Internet's role in implementing education services positively.

On the other hand, 25 of the 97 respondents who represented state higher education institutions in Poland and Ukraine did not agree with the the statement of the role of the Internet in implementing educational services. Based on these data, the value of the Chuprov coefficient $(C=0.332)$ and the value of the Pearson chi-squared test $\left(\chi^{2}=20.444\right)$ were calculated. The observed value of the Pearson chi-squared test $\left(\chi^{2}=20.444\right)$ is significantly higher than its critical (table) value observed value $\chi^{2}$ rather than critical one $\left(\chi_{1-0,01}^{2}(1=(2-1) \times(2-1))=6.635\right)$. This shows with 0.99 significance level that private higher education institutions are more likely to agree on of the positive Internet's role in the delivery of educational services than state ones. The Spearman coefficient was used to estimate the tie density between approval responses for the 12 items between the respondents of Ukraine and Poland. Its estimated value $(\rho=0.773)$ exceeded the critical one $\left(\rho_{1-0,01}(12)=0.73\right)$ at the significance level of 0.99 . This demonstrates the consistency of the opinions of the experts from both countries, who highly agree with the ninth, eighth, fourth, and tenth items, and evaluated the fifth one at the lowest level.

The next step was to clarify the question, "What marketing activities do HEIs use the Internet for, and how often?". The activity system within this question comprised nine items (Table 3). The respondents were offered one of six responses: 1 - "is not used," 2 - "low level of use," 3 - "average level of use," 4 - "high level of use," 5 - "very high level of use," 6 - "I do not know." The last answer was recorded by the respondents for four activities: "Marketing research" (4\% in Poland and 8\% in Ukraine), "Sponsorship" (4\% in Poland and 32\% in Ukraine), "Additional promotion" (27\% in Ukraine), and "E-Commerce" (7\% in Poland). These shares of responses, as well as $2 \%$ of responses of Ukrainian respondents who did not mark any of the six proposed options of answers for "Sponsorship" activities, were not considered in the calculation of the average centred rank. The value of ordinal ranks varied from 1 to 5 (as the Likert scale suggests), and the theoretical value $\bar{R}_{o}$ within the selected rank system ranged from 
-2 to 4 . Significant differences between $\bar{R}_{o}$ for certain items serve as an indicator of reserves of activity improvement, and the maximum value of their sum for two countries $\left(\bar{R}_{o}{ }^{\mathrm{P}}+\bar{R}_{o} \mathrm{U}\right)$ is an indicator of the highest level of activity spread.

Table 3. Average centred ranks and similarity levels of response structures of the respondents in Poland and Ukraine concerning the use of the Internet for higher education institutions' marketing activities

\begin{tabular}{|c|c|c|c|c|c|c|c|c|}
\hline \multirow{3}{*}{ Activities } & \multicolumn{4}{|c|}{$\bar{R}_{o}$} & \multirow{2}{*}{\multicolumn{2}{|c|}{$\bar{R}_{o}^{\mathrm{P}}+\bar{R}_{o}^{U}$}} & \multirow{2}{*}{\multicolumn{2}{|c|}{$P$}} \\
\hline & \multicolumn{2}{|c|}{ Poland $\left(\bar{R}_{0}^{\mathrm{P}}\right)$} & \multicolumn{2}{|c|}{ Ukraine $\left(\bar{R}_{o} \cup\right)$} & & & & \\
\hline & score & rank & score & rank & score & rank & score & rank \\
\hline Marketing research & -0.258 & 7 & 0.098 & 7 & -0.160 & 7 & 0.785 & 4 \\
\hline Student services & 0.980 & 1 & 0.750 & 1 & 1.730 & 1 & 0.880 & 1 \\
\hline $\begin{array}{l}\text { Communication with } \\
\text { students }\end{array}$ & 0.940 & 2 & 0.630 & 3 & 1.570 & 2 & 0.850 & 2 \\
\hline Advertising & 0.450 & 4 & 0.310 & 5 & 0.760 & 4 & 0.835 & 3 \\
\hline Sponsorship & 0.802 & 3 & -0.515 & 9 & 0.287 & 6 & 0.640 & 8 \\
\hline Public relations & 0.400 & 5 & 0.680 & 2 & 1.080 & 3 & 0.740 & 6 \\
\hline Additional promotion & -0.690 & 9 & 0.069 & 8 & -0.621 & 9 & 0.505 & 9 \\
\hline E-learning & -0.080 & 6 & 0.560 & 4 & 0.480 & 5 & 0.770 & 5 \\
\hline E-Commerce & -0.628 & 8 & 0.210 & 6 & -0.418 & 8 & 0.695 & 7 \\
\hline
\end{tabular}

Source: compiled and calculated by the authors based on their own survey.

The two highest total scores of positive $\bar{R}_{o}$ values for both countries (respectively, the highest $P$ values) were obtained for activities related to student services and communication with students. The dominance of $\bar{R}_{o}$ for Poland is due to the fact that none of the respondents from this country pointed to the absence of the Internet use in the processes of providing student services and communicating with them, while a low level for these activities was marked by about $3 \%$ and $2 \%$, respectively. On the other hand, in Ukraine, $2 \%$ of the respondents pointed to the absence of Internet use in the process of providing student services, $7 \%$ - the low level of its use in this process, $8 \%$ - a low level of its use in the process of providing student services. The results of the analysis allow us to state the high effectiveness of communicating between the structural units of an HEI, which uses the tools of Internet marketing, and students.

"Public relations" activities were in third place in the total positive $\bar{R}_{o}$ value for both countries. The $\bar{R}_{o}$ in Ukraine exceeds by $70 \%$ - the same value for Poland - as the share of Ukrainian respondents who indicated the level for this activity as "high," "very high," and "average" was $8 \%, 55 \%$, and 38\%, respectively. The share of Polish respondents was $9 \%, 29 \%$, and $25 \%$, respectively.

Advertising took fourth place according to the overall assessment indicator $\left(\bar{R}_{o}{ }^{\mathrm{P}}+\right.$ $\left.\bar{R}_{o}{ }^{\mathrm{U}}=0,760\right)$ for the two countries. A similar position was given to advertising by respondents from Poland. Here is the value of the average centred $\operatorname{rank}\left(\bar{R}_{o}{ }^{\mathrm{P}}=0,450\right)$ exceeds by $45.2 \%$ the corresponding value for Ukraine $\left(\bar{R}_{o} \mathrm{U}=0,310\right)$, where advertising is in fifth place. However, the value of the coefficient of similarity of response structures concerning Internet use in advertising activities took third place. Maximum 
differences in response structures represented were observed in the assessment of additional promotion ( $9^{\text {th }}$ position) and sponsorship ( $8^{\text {th }}$ position). In this case, the maximum negative assessment by respondents get the "additional promotion" in Poland and "sponsorship" - in Ukraine.

The values of the coefficient of variation (14.9\%) and the interquartile range of variation (0.270), which were calculated on the basis of the $P$ values in Table 2 , indicate the homogeneity of the set of 9 values of the similarity coefficient, the typicality of the average value of the coefficient of structure similarity (0.744), and the absence of significant "outliers" of its values. The observed value of $\rho$, that is calculated based on the values $R_{0}$ Table $3(0.850)$, exceeds the table value $\left(\rho_{1-0,01}(9)=0.83\right)$ in terms of the significance level of 0.99 . This allows us to confirm the consistency of the opinions of the respondents of Poland and Ukraine concerning HEIs marketing activities with the use of the Internet.

The third question was to clarify the extent to which higher education institutions use certain activities within online marketing research. The activity system considered within this question comprised 14 items: 1 - market information analysis with the help of search engines and business directory websites; 2 - market information analysis with the help of specialized websites; 3 - market information analysis from external Internet databases; 4 - market information analysis with the help of discussion forums; 5 - public opinion research through monitoring student activity on social media; 6 - analysis of websites of competing HEIs; 7 - questionnaires on their own webpages (publicly available); 8 - questionnaires on their own webpages (restricted access); 9 - mini-surveys on their own webpages (publicly available); 10 - questionnaires sent via e-mail; 11 - on-line interviews; 12 - interviews in real time via software-communicators; 13 - interviews on discussion forums; 14 - analysis of statistical data from webpages of higher education institutions. They provided a set of answers similar to the previous question (Table 4). Compared to the previous question, here, the respondents chose the answer "I do not know" more often. In particular, more than $10 \%$ of the respondents chose this answer regarding items $\# 1, \# 4, \# 10$, and $\# 11$.

The highest total positive value for both countries was obtained for the activity related to analyzing the competitive environment (\#6), and the most similar response structures were for the activity related to the monitoring of student activity on social media (\#5). The greatest differences in responses were observed in the questions related to interviewing (\#10-\#13). Activities \#12-13 gained maximum negative estimates in both countries.

The values of the coefficient of variation, calculated on the basis of the $P$ values in Table $4(8.9 \%)$ and the interquartile range of variation (0.183), indicate the homogeneity of the set of $14 P$ values, the typicality of the average value of the coefficient of structure similarity (0.698), and the absence of significant "outliers" of P values. The observed value $\rho$, which is calculated based on the values in Table 4 (0.789), exceeds the table value $(\rho 1-0.01(14)=0.68)$ at the significance level of 0.99 . This allows us to confirm the consistency of the opinions of Polish and Ukrainian respondents concerning the activities of HEIs in the framework of online marketing research. 
Table 4. Average centred ranks and similarity levels of response structures of the respondents in Poland and Ukraine concerning the use of certain activities within online marketing research

\begin{tabular}{|c|c|c|c|c|c|c|c|c|c|c|c|}
\hline \multirow{3}{*}{ Activities } & \multirow{2}{*}{\multicolumn{3}{|c|}{$\begin{array}{c}\text { Percentage } \\
\text { of respondents who } \\
\text { said "I don't know" }\end{array}$}} & \multicolumn{4}{|c|}{$\bar{R}_{\circ}$} & \multirow{2}{*}{\multicolumn{2}{|c|}{$\bar{R}_{o}^{\mathrm{P}}+\bar{R}_{o}^{U}$}} & \multirow{2}{*}{\multicolumn{2}{|c|}{$P$}} \\
\hline & & & & \multicolumn{2}{|c|}{$\bar{R}_{o}{ }^{p}$} & \multicolumn{2}{|c|}{$\bar{R}_{0}^{U}$} & & & & \\
\hline & Poland & Ukraine & total & score & rank & score & rank & score & rank & score & rank \\
\hline 1 & 7 & 15 & 10 & 0.430 & 2 & 0.306 & 7 & 0.736 & 3 & 0.760 & 5 \\
\hline 2 & 2 & 10 & 5 & 0.224 & 3 & 0.544 & 2 & 0.768 & 2 & 0.800 & 2 \\
\hline 3 & 7 & 10 & 8 & -0.140 & 6 & 0.278 & 8 & 0.138 & 8 & 0.715 & 8 \\
\hline 4 & 15 & 8 & 13 & -0.212 & 7 & 0.478 & 4 & 0.266 & 6 & 0.720 & 7 \\
\hline 5 & 7 & 4 & 6 & 0.156 & 5 & 0.548 & 1 & 0.704 & 4 & 0.810 & 1 \\
\hline 6 & 0 & 2 & 1 & 0.760 & 1 & 0.357 & 6 & 1.117 & 1 & 0.665 & 10 \\
\hline 7 & 0 & 10 & 3 & -0.230 & 8 & 0.439 & 5 & 0.209 & 7 & 0.790 & 3 \\
\hline 8 & 2 & 8 & 4 & -0.590 & 10 & -0.222 & 11 & -0.812 & 11 & 0.775 & 4 \\
\hline 9 & 0 & 7 & 2 & \begin{tabular}{|l|}
-0.439 \\
\end{tabular} & 9 & 0.13 & 10 & \begin{tabular}{|l|}
-0.309 \\
\end{tabular} & 9 & 0.735 & 6 \\
\hline 10 & 7 & 18 & 11 & -0.950 & 11 & 0.172 & 9 & \begin{tabular}{|l|}
-0.778 \\
\end{tabular} & 10 & 0.510 & 14 \\
\hline 11 & 18 & 39 & 25 & \begin{tabular}{|l|}
-1.439 \\
\end{tabular} & 12 & -0.59 & 12 & \begin{tabular}{|l|}
-2.029 \\
\end{tabular} & 12 & 0.600 & 11 \\
\hline 12 & 0 & 23 & 8 & -1.630 & 13 & -1.156 & 13 & -2.786 & 13 & 0.585 & 13 \\
\hline 13 & 10 & 15 & 12 & -1.911 & 14 & -1.212 & 14 & -3.123 & 14 & 0.600 & 11 \\
\hline 14 & 0 & 8 & 3 & 0.160 & 4 & 0.511 & 3 & 0.671 & 5 & 0.710 & 9 \\
\hline
\end{tabular}

Source: compiled and calculated by the authors based on their own survey.

The next step was to clarify the role of the Internet in marketing research. The analysis of responses revealed high $P$ values for primary and secondary research $(0.925$ and 0.880 , respectively) and their positive values of the $\bar{R}_{o}$ indicator: for Poland -0.720 and 0.840 , respectively; for Ukraine -0.874 and 0.876 , respectively.

A separate part of the research project focused on evaluating forms of advertising HEIs on the Internet. They were represented within 11 groups (Table 5), each of which forecast a set of answers with six options for their use: 1 - "were not used"; 2 - "were used poorly"; 3 - "were used neither well not badly"; 4 - "were used well"; 5 - "were used very well"; 6 - "I do not know." It is noteworthy that in the answers to this part of the research project, the option "I do not know" appeared for all positions.

The value of the coefficient of variation, which is calculated on the basis of the $P$ values according to Table 5 (14.6\%), indicate the homogeneity of the set of $P$ values within the 11 options and the typicality of the average value of the coefficient of structure similarity (0.724). The value of the "Direct e-mail" item (0.470) exceeds the threshold of the interquartile range of variation $\left(R_{Q}=0,820-0.675=0.145\right)$. This can be explained by the attraction of the respondents from Poland to neutral (44\%) and negative assessments (29\%), in return from Ukraine - to positive assessments (58\%) and a high share of missing affirmative answers (23\%).

The observed value of $\rho$, which is calculated based on the $R_{0}$ values in Table 5 (0.901), exceeds the table value $\left(\rho_{1-0,01}(11)=0.76\right)$ at the significance level of 0.99 . This allows us to confirm the consistency of the opinions of the respondents of Poland and Ukraine concerning their assessment of forms of advertising HEIs on the Internet. 
Table 5. Average centered ranks and similarity levels of response structures of the respondents in Poland and Ukraine concerning the evaluation of forms of advertising higher education institutions on the Internet

\begin{tabular}{|c|c|c|c|c|c|c|c|c|c|c|c|}
\hline \multirow{3}{*}{ Activities } & \multirow{2}{*}{\multicolumn{3}{|c|}{$\begin{array}{c}\text { Percentage } \\
\text { of respondents } \\
\text { who said } \\
\text { "I don't know" }\end{array}$}} & \multicolumn{4}{|c|}{$\bar{R}_{\mathrm{o}}$} & \multirow{2}{*}{\multicolumn{2}{|c|}{$\bar{R}_{o}{ }^{\mathrm{P}}+\bar{R}_{o} \mathrm{U}$}} & \multirow{2}{*}{\multicolumn{2}{|c|}{$P$}} \\
\hline & & & & \multicolumn{2}{|l|}{$\bar{R}_{0}^{\mathrm{P}}$} & \multicolumn{2}{|l|}{$\bar{R}_{o}^{U}$} & & & & \\
\hline & $\frac{\text { 믐 }}{\frac{\mathrm{C}}{0}}$ & $\frac{\frac{d}{\frac{L}{0}}}{\frac{5}{5}}$ & $\begin{array}{l}\bar{\pi} \\
\stackrel{8}{\circ} \\
.5\end{array}$ & ֻัँ & 들 & ֻัญ & 亭 & ֻัญ & 픈 & ֻัญ & 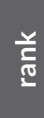 \\
\hline Traditional banners & 2 & 10 & 5 & 0.816 & 3 & 0.856 & 2 & 1.672 & 2 & 0.845 & 1 \\
\hline $\begin{array}{l}\text { Derivative forms } \\
\text { of traditional banners } \\
\text { (e.g., skyscraper, } \\
\text { billboard, other } \\
\text { non-standard size } \\
\text { billboards) }\end{array}$ & 7 & 18 & 11 & -0.495 & 8 & -0.329 & 8 & -0.824 & 8 & 0.815 & 4 \\
\hline Pop-up banners & 7 & 18 & 11 & -0.968 & 10 & -0.610 & 11 & -1.577 & 10 & 0.710 & 7 \\
\hline Interstitial, superstitial & 11 & 23 & 15 & -1.169 & 11 & -0.597 & 10 & -1.766 & 11 & 0.765 & 5 \\
\hline Top layer & 2 & 11 & 5 & -0.908 & 9 & -0.551 & 9 & -1.459 & 9 & 0.820 & 3 \\
\hline Video ads & 5 & 5 & 5 & 0.842 & 2 & 0.674 & 4 & 1.516 & 3 & 0.620 & 10 \\
\hline Sponsored article & 0 & 10 & 3 & -0.150 & 5 & 0.456 & 5 & 0.306 & 5 & 0.720 & 6 \\
\hline Website sponsorship & 22 & 40 & 28 & 0.423 & 4 & -0.183 & 7 & 0.240 & 6 & 0.710 & 7 \\
\hline $\begin{array}{l}\text { Advertising on social } \\
\text { media }\end{array}$ & 0 & 5 & 2 & 1.390 & 1 & 1.168 & 1 & 2.558 & 1 & 0.835 & 2 \\
\hline $\begin{array}{l}\text { Amplifying } \\
\text { on internet-forums }\end{array}$ & 11 & 37 & 20 & -0.382 & 7 & 0.032 & 6 & -0.350 & 7 & 0.675 & 9 \\
\hline Direct e-mail & 7 & 23 & 12 & -0.215 & 6 & 0.792 & 3 & 0.577 & 4 & 0.470 & 11 \\
\hline
\end{tabular}

Source: compiled and calculated by the authors based on their own survey.

Also, the question "Were the advertising activities on the Internet systematically directed (targeted) to a specific audience?" was clarified in the research project. Based on the distribution of answers, we calculated the Chuprov correlation coefficient $(C=0.357)$ and the value of the Pearson chi-squared test ( $\left.\chi^{2}=25.446\right)$, which exceeded the critical value in terms of the significance level of 0.99 $\left(\chi_{1-0,01}^{2}(2=(2-1) \times(3-1))=9.210\right)$. This indicates the predominant direction of the HEIs' activities on the Internet according to the geographical distribution: average - regarding the demographic features, and weak - regarding the behavioral features. 


\section{Conclusion}

The results of the analysis of the response structures of the respondents from Poland and Ukraine verified the main hypotheses of the article. There are practically no differences between the countries regarding the assessments of the Internet role marketing of higher education institutions in Poland and Ukraine. We found consistency in the respondents' answers regarding how much the Internet is used in the marketing activities of HEIs. The same case is for the order of preferable criteria of the audience of higher education by HEIs, i.e., geographic, demographic, behavioral are placed in descending order, respectively.

The representatives of HEIs state that the greatest advantage of the Internet is the quick access to necessary information, which provides higher quality cooperation with students, and improves public relations and the effectiveness of promotional activities. It is widely used for secondary and primary marketing research of HEIs. Most often, the analysis of the competitive environment is carried out online. Opinions were least divided concerning the existing practice of tracking student activities in social media.

The most widespread advertising activities are social media, traditional banners, and video advertising. Advertising activities were the most targeted on a geographical basis.

The study also allows us to outline some ways to improve the marketing activities of HEIs on the Internet. Since private higher education institutions use the Internet more often in marketing activities related to providing educational services, it is advisable for state higher education institutions to expand their activities on the provision of educational services on the Internet. The low level of marketing activity during online interviewing, interviewing with the help of communicator programs, interviewing on discussion forums, and implementing questionnaires via e-mail can serve as a guide to make higher education institutions work more efficiently. The Ukrainian universities should work more for getting sponsors. Polish higher education institutions should focus on Internet-based activities to promote their own brands. They should also focus on e-commerce, market research, and e-learning. It is also advisable to increase the awareness of HEI employees who are involved in marketing, in terms of using the Internet to analyze market information through discussion forums, search engines, and business directory websites; in matters of interviewing and in advertising in the following forms: website sponsorship: amplifying on internet-forums, direct e-mails, derivative forms of traditional banners (e.g., skyscraper, billboard, other non-standard size billboards); pop-up banners. 


\section{References}

Bartosik-Purgat, M. (2018), Nowe media w komunikacji marketingowej przedsiębiorstw na rynku międzynarodowym, Wydawnictwo Naukowe PWN, Warszawa.

Beztelesna, L., Vasyliv, V. (2016), Internet marketing as a formation resource of image policy and competitiveness of University, "Herald of the National University of Water and Environmental Engineering, Rivne”, Vol. 3 (75), pp. 17-29.

Buchnowska, D. (2013), Activity of the best Polish universities on the Facebook social network, "Economic Problems of Services", Vol. 105, pp. 605-614.

Daynovskyy, Y., Semak, B., Boychuk, I. (2018), Digital communication strategies in marketing of higher education services, "Visnyk of Lviv Trade and Economic University. Economic Sciences”, Vol. 56, pp. 5-11. https://doi.org/10.36477/2522-1205-20 18-56-01

Hall, H., Peszko, K. (2016), Social media as a relationship marketing tool of modern university, "Marketing i Zarządzanie”, Vol. 5 (46), pp. 41-56. https://doi.org/10.18 276/miz.2016.46-05

Illiashenko, S. (2014), Internet-marketing of scientifically-educational services. "Scientific works of Donetsk National Technical University. Economic series", Vol. 4, pp. 271-277.

Kisiołek, A. (2018), Internet advertising as a marketing tool of higher education institutions in Poland, "Visnyk of Academician Stepan Demianchuk International University of Economics and Humanities in Rivne", Vol. 2 (20), pp. 51-59.

Kisiołek, A., Karyy, O., Prokopenko, O. (2018), Online marketing of higher education institutions of Poland and the Ukraine in the light of research, "Visnyk of Lviv Polytechnic National University. Series of Logistic”, Vol. 892, pp. 105-113.

Mozgova, G., Kolosovska, O., Onishchenko, V. (2017), Use of the mobile application "INSTAGRAM" as an Internet marketing tool for social communications to promote the brand of higher education institutions and their subdivisions, "Scientific Herald of Kherson State University", Vol. 23 (2), pp. 77-82.

Petrunya, Y., Petrunya, V. (2018), The environment of university activity and marketing aspects of management, "Scientific View: Economics and Management", Vol. 2 (60), pp. 115-121. https://doi.org/10.32836/2521-666X/2018-2-60-16

Prosovych, O., Botsman, Y. (2018), Marketplace as a digital marketing tool, "Journal of Lviv Polytechnic National University. Series of Economics and Management Issues", Vol. 5, No. 897, pp. 32-38. https://doi.org/10.23939/semi2018.01.032

Smyczek, S., Matysiewicz, J. (2015), New Media in Higher Education Market, Publishing House of the University of Economics in Katowice, Katowice.

The 7 hottest higher ed digital marketing trends for 2019. Retrieved from: https://www .higher-education-marketing.com (accessed: 10.07.2019).

The Most Important 2019 Higher Education Marketing Trends. Retrieved from: https:// linchpinseo.com/marketing-trends-in-higher-education/ (accessed: 10.07.2019). 
Wojciechowska, I. (2018), The Scale of Using Social Media by Universities in Poland, "Modern Management Review", Vol. 25 (1), pp. 169-182.

Zabolotskiy, A. (2016), Internet marketing of Distance Learning in Ukrainian Universities (for example, the University of Economics and Law "Krok"). "Youth and the Market", Vol. 3 (164), pp. 164-167.

Zhehus, O. (2018), Forming of the Social Media Marketing strategy of higher education institutions, "Marketing and Digital Technologies", Vol. 2 (2), pp. 58-75. https://doi .org/10.15276/mdt.2.2.2018.5

\section{Streszczenie}

\section{Analiza porównawcza praktycznego wykorzystania internetu w działaniach marketingowych uczelni wyższych w Polsce i na Ukrainie}

W warunkach ery informacyjnej zwiększa się rola szkolnictwa wyższego w systemie czynników stymulujących postęp społeczny, wzrasta też poziom konkurencji w środowisku dostawców tych usług. Wymaga to dywersyfikacji polityki marketingowej instytucji szkolnictwa wyższego, jej digitalizacji i integracji w przestrzeni wirtualnej. W celu zbadania roli narzędzi internetowych i ich znaczenia w działaniach marketingowych przeprowadzono badania ankietowe wśród menedżerów i specjalistów instytucji szkolnictwa wyższego na Ukrainie i w Polsce. Uzyskane dane posłużyły jako podstawa do badania poziomu zmienności, podobieństwa struktur i ogólnej spójności odpowiedzi respondentów z tych dwóch krajów. Zweryfikowano hipotezy dotyczące braku istotnych różnic między przewidywaną rolą Internetu w działalności marketingowej instytucji szkolnictwa wyższego w Polsce i na Ukrainie, spójności odpowiedzi respondentów z tych dwóch krajów na temat poziomu rozpowszechnienia praktyk korzystania z Internetu w działaniach marketingowych instytucji szkolnictwa wyższego oraz docierania przez Internet do potencjalnych studentów przez szkoły wyższe z uwzględnieniem czynników geograficznych.

Dominująca cecha Internetu - szybki dostęp do informacji - umożliwia skuteczne działania marketingowe. Osoby zarządzające szkołami wyższymi powinny zwiększyć świadomość pracowników działów marketingu w zakresie korzystania z Internetu w celu rozszerzenia świadczenia usług edukacyjnych, zintensyfikowania interakcji z klientami, przyciągnięcia sponsorów, promowania własnych marek, badań rynku i tym podobnych.

Słowa kluczowe: instytucja szkolnictwa wyższego, działania marketingowe, marketing internetowy, komunikacja marketingowa, podobieństwa strukturalne, wariacje, korelacja rang 